\title{
Mechanism of Placental Glycogen Deposition in Diabetes in the Rat
}

\author{
V. Barash, A. Gutman and E. Shafrir \\ Department of Clinical Biochemistry, Hebrew University-Hadassah Medical School and Hadassah University Hospital, Jerusalem, Israel
}

\begin{abstract}
Summary. The metabolic basis for glycogen accumulation in the placenta of rats with diabetes induced by streptozotocin on day 12 of pregnancy was studied on days 15 and 20 . On day 15 glycogen content of the placenta was 1.5 -fold higher in the diabetic than in the control rats and this difference increased to $>$ fivefold on day 20 of gestation whether calculated per $g$ tissue or per total placenta. Accumulation of glycogen was associated with increased specific activities of both glycogen synthase and phosphorylase. The activities of these enzymes regulating synthase and phosphorylase activities and the activity of acid $\alpha$-glucosidase were not significantly affected by diabetes. Glucose- 6 -phosphate concentration of the placenta was 67 and $23 \mathrm{nmol} / \mathrm{g}$ in diabetic and control rats, respectively. Incubation of placental homogenates with glucose increased the rate of inactivation of phosphorylase and activa-
\end{abstract}

tion of glycogen synthase. These results indicate that the enhanced glucogenesis in diabetes is not due to changes in the activities of these enzymes, as measured in vitro under standard conditions. The factors promoting glycogen accumulation in vivo are related to the abundance of glucose and glucose-6phosphate as substrates for glycogen synthesis, which may also cause an increase in the activity ratio glycogen synthase $a$ / phosphorylase $a$. In addition, the high intracellular glucose-6phosphate concentration is likely to enable glycogen synthase $b$ to contribute to glycogen synthesis.

Key words: Rat placenta, rat glycogen, pregnancy, diabetic hyperglycaemia, glycogen synthase, phosphorylase, $\alpha-1,4$ glucosidase, glucose-6-phosphate.
An increase in placental glycogen content has been reported in diabetic women [1-2], as well as in rats with experimental diabetes [3-5], however the biochemical events leading to placental glycogen accumulation in diabetes have not yet been clarified.

The rate limiting enzymes of glycogen synthesis and degradation, glycogen synthase and glycogen phosphorylase, are present in the placenta, as in other tissues, in two interconvertible forms $a$ and $b[6]$. Huang and Robinson $[7,8]$ identified and purified the inactive $b$ form of glycogen synthase from human term placenta and also demonstrated the existence of phosphatase and kinase activities, responsible for the activation or inactivation of glycogen synthase. Yarimagan and Bor [9] showed that adrenaline, via cyclic AMP, activates phosphorylase and inactivates glycogen synthase in the placenta, as in other tissues.

Conflicting reports exist on the effect of insulin on placental glycogen metabolism. Demers et al. [6] suggested that insulin accelerates the synthesis of glycogen in the placenta, as in muscle or liver, but Szabo and Gri- maldi [10] found no support for this contention. There is no clearcut evidence that placental metabolism or glucose transport are facilitated by insulin. Conversely, diabetes is not associated with changes in insulindependent enzyme activities in the placenta, as it is in liver or adipose tissue [5].

In the diabetic state only few investigations on the activities of glycogen synthase and phosphorylase in the placenta are available. Gabbe et al. [2] observed in term placenta of diabetic women an increase in the activity of phosphorylase $a$ and $b$ and a decrease of glycogen synthase $a$. Abramovici et al. [4] found a marked reduction of both forms of glycogen synthase activity, but no appreciable change in those of phosphorylase, in the placenta of rats with preconception diabetes. Such changes in enzyme activities would not be expected to promote placental glycogen deposition.

In view of the incomplete information on the placental metabolism of glycogen in diabetes and the fact that numerous placental enzyme activities decrease with the progress of pregnancy [11, 12], the activities of 
enzymes and concentrations of metabolites with regulatory implications on glycogen synthesis and breakdown were studied at two points of time during gestation in the rat.

\section{Materials and Methods}

\section{Animals and Tissue Preparation}

Female and male albino rats of the Hebrew University strain, weighing 200-250 g, were caged together for one night from 17.00 to $09.00 \mathrm{~h}$. Diabetes was induced on day 12 of pregnancy by IP injection of streptozotocin $(65 \mathrm{mg} / \mathrm{kg}$, freshly dissolved in $5 \mathrm{mmol} / 1$ citrate buffer, $\mathrm{pH}$ 4.5).

On day 15 or 20 of pregnancy the animals were decapitated and blood was collected. Fetal blood was collected into glass capillaries from an incision of the carotid artery and pooled for each litter within $3 \mathrm{~min}$ after decapitation. Serum glucose was determined by a hexokinase method, triglycerides by a kinetic, fully enzymatic lipase - glycerokinase spectrophotometric procedure, non-esterified fatty acids (NEFA) by a radiochemical assay [13] and insulin by a double-antibody radioimmunoassay kit (Amersham Radiochemical Centre, Bucks, UK). The enzymatic determinations were carried out with reagents from Boehringer (Mannheim, FRG) and procedures adapted to the Centrifichem centrifugal analyzer (Union Carbide, Rye, NY, USA).

The placenta were washed, weighed and homogenized in 4 volumes of $50 \mathrm{mmol} / \mathrm{l}$ Hepes buffer (N-2-hydroxyethylpiperazine-Nethanesulfonic acid), pH 7.4, containing dithioerythreitol $(2 \mathrm{mmol} / 1)$. The homogenates were centrifuged at $6000 \times g$ for $20 \mathrm{~min}$ and the supernatant fluid used as the enzyme source. Maternal and pooled fetal livers were also taken for determination of glycogen content.

\section{Determination of Glucose-6-Phosphate (G-6-P) and Glycogen}

Glycogen was determined enzymatically [14] after digestion of the tissues in $30 \%(\mathrm{w} / \mathrm{v}) \mathrm{KOH}$ and precipitation of the glycogen at $60 \%(\mathrm{v} / \mathrm{v})$ ethanol. For the determination of G-6-P content, the placentas were quickly frozen in liquid air. Tissue extracts were prepared by deproteinisation of the frozen tissue with $\mathrm{HC}_{4} \mathrm{O}_{4},(0.6 \mathrm{~mol} / \mathrm{l})$, and neutralim sation with $\mathrm{K}_{2} \mathrm{CO}_{3}$. The extracts were then concentrated by lyophilisation and G-6-P was determined by the method of Lowry et al. [15].

\section{Assay of Enzymes of Glycogen Metabolism}

Glycogen synthase activity $a$ was determined by following the incorporation of glucose from UDP- $\left[{ }^{14} \mathrm{C}\right]$ glucose into glycogen. The reaction mixture $(60 \mu \mathrm{l})$, contained $1.6 \mathrm{mmol} / \mathrm{l}$ UDP-[U- $\left.{ }^{14} \mathrm{C}\right]$-glucose, $0.25 \mathrm{Ci} / \mathrm{mol}$ (Radiochemical Centre, Amersham, Bucks, UK), Hepes buffer, pH $8.0(80 \mathrm{mmol} / \mathrm{l})$ shellfish glycogen $(1 \%)$ and placental homogenate $(10 \mu \mathrm{l})$. For the determination of total glycogen synthase activity $(a+b)$, G-6-P $(5 \mathrm{mmol} / 1)$ was added. Incubation lasted $15 \mathrm{~min}$ at $30^{\circ} \mathrm{C}$ and was terminated by application of the assay mixture $(50 \mu \mathrm{l})$ to Whatman ET 31 filter paper [16].

Phosphorylase $a$ and total phosphorylase $(a+b)$ activities were determined by the method of Tan and Nuttall [17]. The reaction mixture $(50 \mu \mathrm{l})$, contained $60 \mathrm{mmol} / 1\left[{ }^{14} \mathrm{C}\right]$ glucose-1-phosphate, $0.2 \mathrm{Ci}$ / mol (Radiochemical Centre, Amersham, Bucks, UK), MES (2[N-morpholino] ethane sulfonic acid) buffer $\mathrm{pH} 6.1(60 \mathrm{mmol} / \mathrm{l})$, shellfish glycogen (1\%) and NaF $(100 \mathrm{mmol} / 1)$. For the determination of phosphorylase $(a+b)$ activities 5 -AMP $(2 \mathrm{mmol} / \mathrm{l})$ was added. The activities of glycogen synthase and phosphorylase were defined as nmol/ min of $\left[{ }^{14} \mathrm{C}\right]$-glucose incorporated into glycogen from UDP-glucose or glucose-1-phosphate, respectively, per mg of homogenate protein.
The activities of glycogen synthase phosphatase (conversion of $b$ to $a$ form) and phosphorylase phosphatase (conversion from $a$ to $b$ form) were determined in the placental homogenates incubated at $30^{\circ} \mathrm{C}$ for $30 \mathrm{~min}$. Samples were removed at $5 \mathrm{~min}$ intervals and assayed for glycogen synthase and phosphorylase activity as described above. The activity changes were read from the linear portion of the activity/incubation time curves and expressed as $\mathrm{nmol} \cdot \mathrm{min}^{-1} \cdot \mathrm{mg}^{-1}$ homogenate protein.

Glycogen synthase and phosphorylase kinases were measured by following the activities of glycogen synthase $a$ and phosphorylase $a$, at $30 \mathrm{~s}$ intervals, during the incubation of placental homogenates in the presence of ATP $(5 \mathrm{mmol} / 1), \mathrm{MgCl}_{2}(10 \mathrm{mmol} / \mathrm{l})$ and $3^{\prime}, 5^{\prime}$ dibutyryl cyclic $\operatorname{AMP}(0.5 \mathrm{mmol} / \mathrm{l})$.

Acid $\alpha$-1,4-glucosidase activity was measured fluorometrically [18]. The reaction mixture $(0.2 \mathrm{ml})$, contained 4-methyl umbelliferyl$\alpha$-D glucoside $(0.2 \mathrm{mmol} / \mathrm{l})$, acetate buffer, $\mathrm{pH} 4.3(50 \mathrm{mmol} / 1)$ and $20 \mu \mathrm{l}$ of placental homogenate. After incubation for $10 \mathrm{~min}$ at $30^{\circ} \mathrm{C}$ the reaction was terminated by addition of $2.8 \mathrm{ml}$ of glycine buffer, pH $10.3(1 \mathrm{~mol} / \mathrm{l})$.

The homogenate protein content was determined with Ponceau red [19]. Statistical evaluations were done by the Student's t-test for non-paired groups.

\section{Results}

Glucose, insulin, NEFA and triglyceride levels in fetal and maternal rat serum are shown in Table 1 . On both days 15 and 20 of gestation, 3-8 days after the onset of diabetes, there was an approximately fivefold increase in maternal serum glucose. Fetal serum glucose, determined on day 20 of pregnancy, was also considerably increased. The maternal plasma content of triglycerides and NEFA rose markedly, attesting to the severity of diabetes.

\section{Placental Glycogen Content}

On day 15 of pregnancy, 3 days after the induction of diabetes, the concentration of glycogen in the placenta was already elevated (Table 2 ). The glycogen content/g tissue decreased with gestation both in control and diabetic animals, but the rate of decrease was more pronounced in the control rats (fivefold versus twofold), so that the difference in glycogen content became considerably greater on day 20 of pregnancy. Since the placental weight increased with gestation there was some compensation for the specific glycogen loss, but the difference persisted. When expressed per total placenta, the glycogen content actually rose with gestation in diabetic rats, while it fell in control rats.

Table 2 also shows that the accumulation of glycogen in the placenta of diabetic rats was in contrast to the disappearance of glycogen from maternal liver, in the face of maternal hypoinsulinaemia (Table 1). On the other hand, the hepatic glycogen of the fetuses of diabetic rats, compared with fetuses of control rats, showed a small but significant increase which was associated with fetal hyperglycaemia (Table 1). Fetal serum insulin levels were increased in comparison with maternal serum, but no significant difference between fetuses from 
Table 1. Maternal and fetal serum metabolites in control and diabetic rats on days 15 and 20 of gestation

\begin{tabular}{|c|c|c|c|c|c|c|}
\hline Rats & \multicolumn{4}{|l|}{ Maternal serum } & \multicolumn{2}{|l|}{ Fetal serum } \\
\hline Control & $4.9 \pm 0.4$ & $9.8 \pm 1.2$ & $515 \pm 62$ & $64 \pm 7$ & - & - \\
\hline Diabetic & $22.5 \pm 1.9$ & $29.1 \pm 2.8$ & $890 \pm 105$ & $11 \pm 4$ & - & - \\
\hline Control & $4.7 \pm 0.3$ & $20.5 \pm 2.1$ & $648 \pm 48$ & $58 \pm 6$ & $1.5 \pm 0.2$ & $93 \pm 10$ \\
\hline Diabetic & $23.5 \pm 1.6$ & $46.1 \pm 3.4$ & $1115 \pm 118$ & $15 \pm 3$ & $13.5 \pm 0.5$ & $102 \pm 8$ \\
\hline
\end{tabular}

Values are expressed as mean \pm SEM for $12-14$ rats

Table 2. Glycogen content of placenta, maternal and fetal liver in control and diabetic rats

\begin{tabular}{|c|c|c|c|c|c|}
\hline \multirow[t]{2}{*}{ Rats } & \multirow{2}{*}{$\begin{array}{l}\text { Placental } \\
\text { weight } \\
\text { (mg) }\end{array}$} & \multicolumn{4}{|c|}{ Glycogen content } \\
\hline & & $\begin{array}{l}\text { Placenta } \\
\text { (mg/g) }\end{array}$ & $\begin{array}{l}\text { Placenta } \\
\text { (mg, total) }\end{array}$ & $\begin{array}{l}\text { Maternal } \\
\text { liver } \\
(\mathrm{mg} / \mathrm{g})\end{array}$ & $\begin{array}{l}\text { Fetal } \\
\text { liver } \\
(\mathrm{mg} / \mathrm{g})\end{array}$ \\
\hline \multicolumn{6}{|l|}{ Day 15} \\
\hline Control & $158 \pm 11$ & $12.7 \pm 0.9$ & $2.0 \pm 0.1$ & $53.8 \pm 4.3$ & - \\
\hline Diabetic & $162 \pm 24$ & $19.2 \pm 2.0^{\mathrm{a}}$ & $3.1 \pm 0.2^{a}$ & $13.6 \pm 2.1^{a}$ & - \\
\hline \multicolumn{6}{|l|}{ Day 20} \\
\hline Control & $402 \pm 17$ & $2.3 \pm 0.3$ & $0.9 \pm 0.1$ & $39.8 \pm 3.5$ & $53.1 \pm 3.5$ \\
\hline Diabetic & $475 \pm 18^{\mathrm{a}}$ & $11.2 \pm 0.7^{\mathrm{a}}$ & $5.3 \pm 0.2^{*}$ & $12.5 \pm 1.8^{\mathrm{a}}$ & $65.5 \pm 4.0^{\mathrm{a}}$ \\
\hline
\end{tabular}

Values are expressed as mean \pm SEM for 12-14 rats. Each glycogen determination and placental weight represents an average of three placenta from each lit-

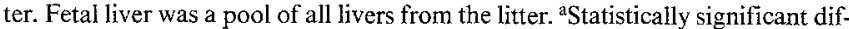
ference (Student's t-test) at $p \leqslant 0.05$ (diabetes versus control)

diabetic and control rats, which could be related to the placental or hepatic glycogen increases, was evident.

\section{Placental Enzymes of Glycogen Metabolism}

The total activity of glycogen synthase $(a+b)$ was about 1.5 -fold higher in the diabetic compared with control rats both on days 15 and 20 of gestation
(Table 3). The percentage of the active form $(a / a+b)$ ranged from $15-19 \%$ of the total and did not vary appreciably between the control and diabetic animals. With respect to the effect of the duration of pregnancy it should be noted that the specific activity of glycogen synthase remained stable between days 15 and 20 in control or diabetic rats. However, due to increase in placental size, a two- to threefold increase in glycogen synthase capacity occurred, when expressed per total placenta and the difference between control and diabetic rats became even more significant.

The specific activity of placental glycogen phosphorylase $(a+b)$ also increased as a result of diabetes, slightly on day 15 and about 1.7 -fold on day 20 of pregnancy (Table 3$)$. The percentage of active form ( $a / a+$ $b$ ) was lower in the diabetic rats. It was about 71 and $46 \%$ of the total on days 15 and 20 of pregnancy, compared with 80 and $66 \%$, respectively, in the control rats. The specific activity of placental glycogen phosphorylase tended to decrease during the gestation both in control and diabetic rats, in contrast to glycogen synthase, but this decrease was compensated by the increase in total capacity, when expressed per placenta.

Table 3 also shows the activity of acid- $\alpha$-glucosidase, an enzyme of lysosomal origin, participating in

Table 3. Activity of placental giycogen synthase, phosphorylase and acid $\alpha$-glucosidase in control and diabetic rats

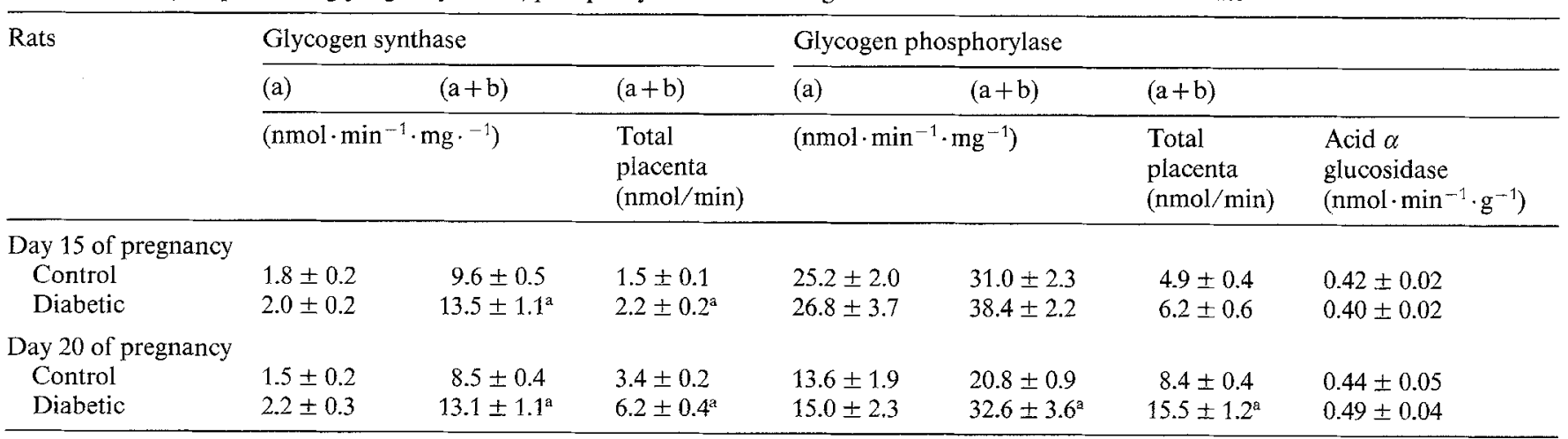

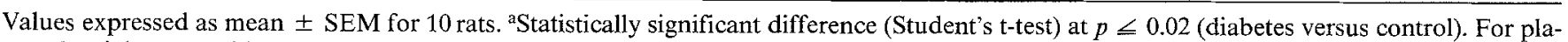
cental weights see Table 2 


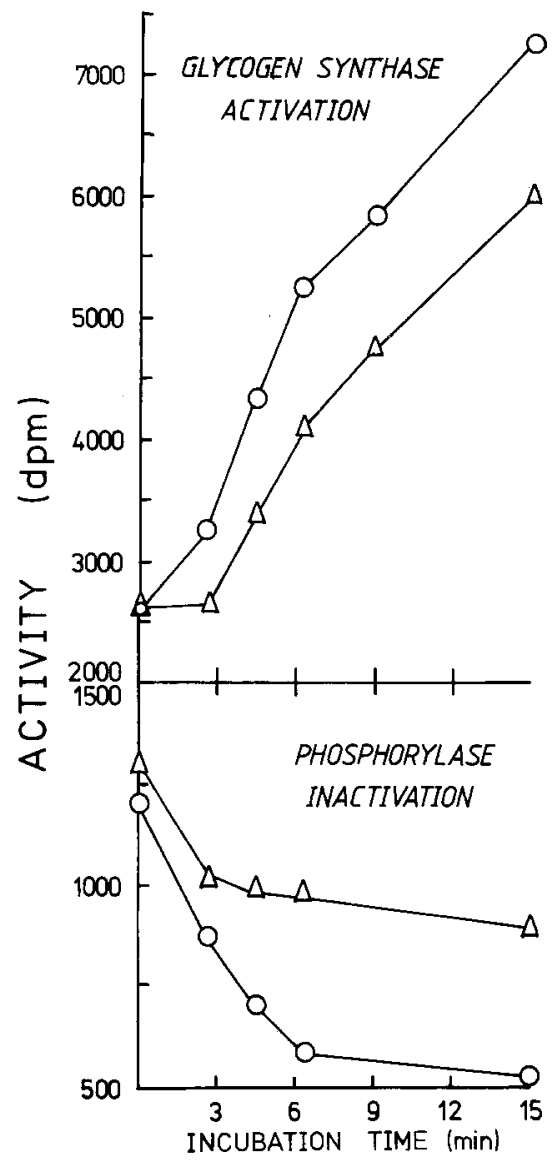

Fig. 1. Effect of glucose on glycogen synthase activation (conversion $b$ to $a$ ) and phosphorylase inactivation (conversion $a$ to $b$ ) in the presence of $1.5 \mathrm{mmol} / 1(\Delta)$ and $8 \mathrm{mmol}(O)$ of glucose. Measurements were made in whole placental homogenates at $30^{\circ} \mathrm{C}$ (see Methods)

glycogen degradation in liver, muscles and other tissues and lacking in Type II glycogen storage disease [20]. The values in Table 3 indicate that the specific activity of this enzyme in the placenta remained stable between days 15 and 20 of gestation and there was no significant change as a result of diabetes.

The interconversion of the two forms of glycogen synthase and phosphorylase is dependent on the relative activities of their respective phosphatases and kinases. The activity of these enzymes in placental homogenates were calculated from multiple point kinetics of synthase activation or phosphorylase inactivation. The results of a representative experiment show that on day 15 of pregnancy the activities of glycogen synthase phosphatase and kinase were similar in diabetic and control rats $(4.7$ versus 5.1 and 17.4 versus $17.0 \mathrm{nmol}$. $\mathrm{min}^{-1} \cdot \mathrm{mg}^{-1}$, respectively). The activities of phosphorylase phosphatase and kinase were also similar $(10.8$ versus 12.5 and 41.1 versus $39.1 \mathrm{nmol} \cdot \mathrm{min}^{-1} \cdot \mathrm{mg}^{-1}$, respectively). On day 20 of pregnancy the activities of glycogen synthase phosphatase and kinase slightly rose but again without significant difference between diabetic and control rats (5.2 versus 7.0 and 18.4 versus $21.7 \mathrm{nmol} \cdot \mathrm{min}^{-1} \cdot \mathrm{mg}^{-1}$, respectively). The activities of phosphorylase phosphatase and kinase rose more markedly with gestation, but were not appreciably different in the diabetic and control rats (17.2 versus 14.6 and 67.7 versus $73.4 \mathrm{nmol} \cdot \mathrm{min}^{-1} \cdot \mathrm{mg}^{-1}$, respectively). Diabetes did not seem, therefore, to affect these placental enzymes.

\section{Effect of Hyperglycaemia on Glycogen Metabolism}

Since the placenta of diabetic rats was exposed to hyperglycaemia on both maternal and fetal sides, we explored the effect of elevated glucose concentration in vitro on the activity of glycogen phosphorylase $a$ and glycogen synthase $a$ in placental homogenates. Figure 1 shows that the rates of activation of glycogen synthase (conversion of $b$ to $a$ form) and of inactivation of glycogen phosphorylase (conversion of $a$ to $b$ form) were enhanced by increasing the concentration of glucose in the homogenates of placenta from control rats. The effect of glucose on the activitiy of these enzymes in the homogenates from diabetic animals was of similar magnitude (results not shown).

The intracellular concentration of G-6-P is also dependent on the ambient glucose concentration and plays a significant role in the regulation of the activities of glycogen and phosphorylase [21, 22]. Determination of cellular G-6-P concentration showed a threefold increase in the placenta of diabetic rats on day 20 of pregnancy $(67.0 \pm 5.9$ versus $23.0 \pm 3.3 \mathrm{nmol} / \mathrm{g}$, mean \pm SEM for six rats). The association constant (Ka) of glycogen synthase toward G-6-P remained unchanged ( 0.30 versus $0.28 \mathrm{mmol} / 1$ in diabetic and control rats, respectively).

\section{The Relationship of Fat Substrate Availability to Placental Glucose Metabolism}

The plasma of diabetic animals is rich in NEFA and triglycerides (Table 1) and the triglyceride content in the placenta of diabetic rats was found to be elevated [23]. Therefore, the possibility was explored that the excessive availability of fatty acids and their increased utilization by the placenta may cause an inhibition of glycolysis by products of their oxidation, which in turn may contribute to the increase in G-6-P levels and promote the channeling of glucose into glycogen. In several experiments, placenta from control rats on day 20 of gestation were incubated for $2 \mathrm{~h}$ in Krebs-Ringer bicarbonate buffer containing $\left[\mathrm{U}-{ }^{14} \mathrm{C}\right]$-glucose $(10$ $\mathrm{mmol} / \mathrm{l}$ ) and $2 \%$ bovine albumin. The incorporation of glucose carbons to glycogen, triglycerides, carbon dioxide and lactate was measured. The addition of citrate at concentrations $\leqslant 1 \mathrm{mmol} / 1$ or palmitate at concentrations $\leqslant 0.64 \mu \mathrm{mol} / \mathrm{ml}$ (molar ratio NEFA/albumin $>2$ ) did not effect a significant change in the relative rates of incorporation of glucose carbons or their distribution among the various products (results not shown). 


\section{Discussion}

The accumulation of glycogen in the placenta of diabetic rats was accompanied by an increase in glycogen synthase and phosphorylase acitivities. Other enzymes which could have affected the rate of synthesis or degradation of glycogen, such as the phosphatases and kinases regulating glycogen synthase and phosphorylase activity, or acid- $\alpha$-glucosidase remained virtually unaffected. In our rat model diabetes was induced on day 12 of pregnancy in order to avoid the placental deterioration, fetal resorption and malformations often seen in rats with preconception diabetes [24, 25]. Abramovici et al. [4], who have used the latter model, found no changes in the activity of phosphorylase and a marked decrease in the activity of glycogen synthase on day 20 of pregnancy. Demers et al. [6] found an increase in phosphorylase and a decrease in glycogen synthase activities in term placenta from diabetic women. Abramovici et al. [4] also found a threefold increase in the activity of $\alpha$-glucosidase. Although some of these observations differ from ours, particularly with regard to glycogen synthase and $\alpha$-glucosidase, none of the recorded diabetes-induced activity changes are conducive towards enhanced glycogenesis.

A diabetes-related increase in the availability of glucose as substrate and activator and subsequent changes in the concentration of G-6-P and other intracellular regulatory metabolites are, therefore, more likely to be responsible for the accumulation of placental glycogen in diabetes. Glucose and G-6-P affect glycogen synthase and phosphorylase in several ways. Glucose binds to phosphorylase $a$, thereby promoting its conversion to the inactive $b$ form and reducing the affinity of the enzyme for its substrate $[26,27]$. On the other hand, glucose was demonstrated to stimulate the conversion of liver glycogen synthase $b$ to the $a$ form; this conversion is inhibited by phosphorylase $a$, whereas glucose relieves this inhibition by promoting the inactivation of phosphorylase $a$ [28]. G-6-P is an important activator of glycogen synthase $b$ in vitro. However, the magnitude of the in vivo effect of this ligand on the contribution of synthase $b$ to glycogenesis is unclear since the affinity of glycogen synthase $b$ for G-6-P is modulated by the concentrations of phosphate, magnesium or manganese ions and of adenine nucleotides [7, 8]. An effect of G6-P on the $b$ to $a$ conversion of glycogen synthase has been demonstrated in several tissues, such as spleen [29] and adipocytes [22]. The glucose-induced activation of glycogen synthase and inactivation of phosphorylase in placental homogenates, together with the pronounced increase in cellular G-6-P shown here, point to hyperglycaemia as the main causative factor for the accumulation of placental glycogen. As mentioned in the Results, citrate or NEFA do not promote placental glycogen synthesis from glucose in vitro, in contrast to the rise in muscle glycogen related to the inhibition of glycolysis in a situation of enhanced NEFA utilisation [30].
This failure may be due to the role of glycolysis as the main energy supply pathway in the placenta as inferred from its low oxidative capacity (production of carbon dioxide from glucose is only one tenth that of lactate) [31], as well as from the low rate of carbon dioxide production from palmitate [32] compared with liver or muscle. This situation may preclude the build-up of fatty acid oxidation products, sufficient to inhibit pyruvate dehydrogenase or phosphofructokinase, even when NEFA are available in excess. Placental rise in G-6-P seems to result, then, from the hyperglycaemia-augmented glucose uptake rather than from the inhibition of G-6-P metabolism.

The activities of placental enzymes of several metabolic pathways (e.g. pyruvate kinase, NADP-malate dehydrogenase and alanine aminotransferase) have been shown to decrease with gestation at different rates [33]. We have noted no changes in the activities of glycogen synthase and $\alpha$-glucosidase and only a small decrease in that of phosphorylase between days 15 and 20 of gestation, both in control and diabetic rats. These observations support the previous conclusions that the changes in enzyme activities should be ascribed to specific factors determining the decay kinetics of individual enzymes rather than to general placental aging [33]; these factors seem unaffected by diabetes.

Diabetes enhanced the activities of both glycogen synthase and phosphorylase in the placenta, although their activities in liver, muscle and adipose tissue are well known to decrease in this condition. It is possible that the hyperglycaemia-related accumulation of glycogen may have a stabilizing action on these enzymes, which are normally attached to the glycogen particles in the cell [34]. This possibility is supported by recent observations on liver phosphorylase kinase-deficient rats ( $g s d / g s d$ ), in which glycogen storage is accompanied by increased levels of glycogen synthase [35]. The involvement of insulin has also to be considered, as glycogenesis is insulin-dependent in liver, muscle and adipose tissue. However, glycogen accumulation in the placenta, in the face of maternal insulin deficiency and with hyperinsulinaemia on the fetal side being not more marked in diabetic than control rats, indicates that insulin has no direct influence on glycogen metabolism in this tissue. It is pertinent that, in analogy, there is no effect of diabetes on several insulin susceptible enzymes in the placenta [5]. In this respect, the placenta resembles other insulin-independent tissues, in which the activity of glycogen synthase and glycogen content are either unaffected, or increased in diabetes, such as adrenal gland [36], kidney [37], intestine [38] and leucocytes [39].

Acknowledgement. The experimental assistance of S.Lilling and S. Bonjake is gratefully acknowledged. Supported in part by a grant from the Joint Research Fund of the Hebrew University and Hadassah. 


\section{References}

1. Heikensjold F, Gemzell CA (1957) Glycogen content in the placenta of diabetic mothers. Acta Paediatr Scand 46: 74-80

2. Gabbe SG, Demers LM, Greep RO, Villee CA (1972) Placental glycogen metabolism in diabetes mellitus. Diabetes 21: 1185-1191

3. Hagerman DD (1962) Metabolism of tissues from pregnant diabetic rats in vitro. Endocrinology 70:88-89

4. Abramovici A, Sporn S, Prager R, Shaltiel A, Laron Z, Liban E (1978) Glycogen metabolism in the placenta of streptozotocin diabetic rats. Horm Metab Res 10: 195-199

5. Diamant YZ, Shafrir E (1979) Placental enzymes of glycolysis, gluconeogenesis and lipogenesis in the diabetic rat and in starvation. Comparison with maternal and fetal liver. Diabetologia 15: 481-485

6. Demers CM, Gabbe SG, Villee CA, Greep RO (1972) The effects of insulin on human placental glycogenesis. Endocrinology 91: $270-275$

7. Huang KP, Robinson SC (1976) Purification and properties of the glucose-6-phosphate dependent form of human placental glycogen synthase. Arch Biochem Biophys 175: 583-589

8. Huang KP, Robinson SC (1977) Effect of manganese ions and sulfate on activity of human placental glucose-6-phosphate dependent form of glycogen synthase. J Biol Chem 252: 3240-3244

9. Yarimagan HS, Bor NM (1981) The effects of epinephrine on guinea pig placental glycogen metabolism and on cellular cyclic AMP. Biochem Med 25: 125-134

10. Szabo AJ, Grimaldi RD (1970) The effect of insulin on glucose metabolism of the incubated human placenta. Am J Obstet Gynecol 106: 75-78

11. Diamant YZ, Shafrir E (1972) Enzymes of carbohydrate and lipid metabolism in the placenta and liver of pregnant rats. Biochim Biophys Acta 279: 424-430

12. Remesar X, Aroca L, Palou A, Alemany M (1980) Activities of enzymes involved in amino metabolism in developing rat placenta. Europ J Biochem 110: 289-293

13. Ho RJ (1970) Radiochemical assay of long-chain fatty acids using $68 \mathrm{Ni}$ as tracer. Anal Biochem 36:105-113

14. Johnson JA, Fusaro RM (1964) An enzymic method for the quantitative determination of micro quantities of glycogen. Anal Biochem 7: 189-191

15. Lowry OH, Passoneau SV, Hasselberger FX, Schulz DW (1964) Effect of ischemia on known substrates and cofactors of the glycolytic pathway in brain. J Biol Chem 239: 18-30

16. Thomas JA, Schlender KK, Larner J (1968) A rapid filter paper assay for UDP-glucose glycogen glycosyl transferase including an improved biosynthesis of $\mathrm{UDP}^{14} \mathrm{C}$-glucose. Anal Biochem 25: 486-499

17. Tan AWH, Nuttall FO (1975) Characteristics of the dephosphorylated form of phosphorylase purified from rat liver and measurement of its activity in crude liver preparation. Biochim Biophys Acta 410: 45-60

18. Salafsky IS, Nadler HL (1973) Deficiency of acid alpha glucosidase in the urine of patients with Pompe's disease. J Pediatr 82: 294-297

19. Ponceau MA, Strande CS (1973) A new micromethod for the determination of protein in cerebrospinal fluid and urine. Clin Chem 19: 1265-1267

20. Hers HG (1963) $\alpha$-glucosidase deficiency in generalized glycogen storage disease (Pompe's disease). Biochem J 86: 11-21

21. Kato K, Bishop JS (1972) Glycogen synthase-D-phosphatase. J Biol Chem 247: 7420-7429

22. Sobrino F, Hers HG (1980) The inactivation of phosphorylase and activation of glycogen synthase in adipose tissue. Europ J Biochem 109: 239-246

23. Shafrir $E$, Khassis $S$ (1982) Maternal-fetal fat transport versus new fat synthesis in the pregnant diabetic rat. Diabetologia 22: 111-117

24. Foglia VG, Chieri RA, de Peralta Ramos MC (1970) Mechanism of disturbances during pregnancy in the diabetic female rat. Horm Metab Res 2: 76-80

25. Prager R, Abramovici A, Liban E, Laron Z (1974) Histopathological changes in the placenta of streptozotocin induced diabetic rats. Diabetologia 10: 89-91

26. Stalmans W, Laloux M, Hers HG (1974) The interaction of liver phosphorylase $a$ with glucose and AMP. Europ J Biochem 49: 415-427

27. Bailey JM, Whelan W (1972) The roles of glucose and AMP in regulating the conversion of phosphorylase $a$ into phosphorylase $b$. Biochem Biophys Res Comm 46: 191-197

28. Stalmans W, De-Wulf H, Hue L, Hers HG (1974) The sequential inactivation of glycogen phosphorylase and activation of glycogen synthase in liver after the administration of glucose to mice and rats. Europ J Biochem 41: 127-134

29. Hizukuri S, Takeda Y (1970) Activation of the D to I form conversion of glycogen synthase by glucose-6-phosphate in bovine spleen. Biochim Biophys Acta 212: 179-181

30. Randle PJ (1966) Carbohydrate metabolism and lipid storage and breakdown in diabetes. Diabetologia 2: 237-247

31. Beyth Y, Neuman S, Gutman A, Shafrir E (1977) Effect of prolonged gestation on placental and maternal liver enzyme activities in the rat. Diabete Metab 3:91-96

32. Diamant YZ, Diamant S, Freinkel N (1980) Lipid deposition and metabolism in rat placenta during gestation. Placenta 1: 319--325

33. Shafrir E, Diamant YZ (1979) Regulation of placental enzymes of the carbohydrate and lipid metabolic pathways. In: Beard RW, Hoet JJ (eds). Symposium on Pregnancy Metabolism, Diabetes and the Foetus Ciba Foundation, London, pp 161-179

34. Luck DJL (1961) Glycogen synthesis from uridine diphosphate glucose. The distribution of the enzyme in liver cell fractions. J Biophys Biochem Cytol 10: 195-198

35. Malthus R, Clark DG, Watts C, Sneyd GT (1980) Glycogen-storage disease in rats; a genetically determined deficiency of liver phosphorylase. Biochem J 188: 99-101

36. Bindstein E, Piras R, Piras MM (1971) Regulation of glycogen metabolism in the adrenal gland. Endocrinology 88: 233-239

37. Khandelwal RL, Zinman SM, Knull HR (1979) The effect of streptozotocin-induced diabetes on glycogen metabolism in rat kidney and its relationship to the liver system. Arch Biochem Biophys 197:310-316

38. Anderson JW, Jones AL (1974) Biochemical and ultrastructural study of glycogen in jejunal mucosa of diabetic rats. Proc Soc Exp of Med 145: 268-272

39. Boneh A, Gutman A, Nahas N (1980) Glycogen synthase activity in polymorphonuclear leukocytes from diabetic patients and rats with experimental diabetes. Israel J Med Sci 17: 60 (Abstract)

Received: 21 April 1982

and in revised form: 27 July 1982

Professor E. Shafrir

Department of Biochemistry

Hadassah University Hospital

P.O. Box 12000

Jerusalem 91120, Israel 